\title{
Reduced graphene oxide coated graphite electrodes for treating Reactive Turquoise Blue 21 rinse water using an indirect electro-oxidation process
}

\author{
Naresh R. Vaghela ${ }^{1} \cdot$ Kaushik Nath ${ }^{2}$
}

Received: 27 August 2020 / Accepted: 14 October 2020 / Published online: 18 October 2020

(c) Springer Nature Switzerland AG 2020

\begin{abstract}
The present study deals with the decolourization of synthetic Reactive Turquoise Blue 21 (RTB21) dye-based model wastewater using an indirect electro-oxidation process and enhanced by modified graphite electrodes. Graphene oxide (GO) was successfully synthesized and deposited on the surface of pre-treated graphite electrodes. It was further reduced to form reduced graphene oxide ( $\mathrm{rGO}$ ). The resultant newly developed anode electrodes were designated as $(\mathrm{Gr})_{0},(\mathrm{rGO} /$ $\mathrm{Gr})_{1}$, and $(\mathrm{rGO} / \mathrm{Gr})_{2}$ and used for the treatment of wastewater. Electrodes, thus developed, were characterized using Fourier-transform infrared spectroscopy, X-ray diffractions, Field emission scanning electron microscopy, and Contact angle (CA). The effect of process parameters such as initial $\mathrm{pH}$, current density, electrolyte concentration, and temperature on the performance of novel anode electrodes was investigated. The colour removal efficiency was increased significantly almost $25.80 \%$ in the presence of a modified electrode with the highest efficiencies of about $96.69 \%$ in a natural $\mathrm{pH}$ environment, $200 \mathrm{~A} / \mathrm{m}^{2}, 2 \mathrm{~g} / \mathrm{L} \mathrm{NaCl}$ concentration, $30^{\circ} \mathrm{C}$ temperature, and $15 \mathrm{~min}$ process time for $50 \mathrm{ppm}$ RTB21 dye concentration for ( $\mathrm{rGO} / \mathrm{Gr})_{2}$ electrode. The RTB21 decolourization by indirect electro-oxidation process follows the pseudo-first-order kinetics, and the activation energy was estimated to be $23.42 \mathrm{~kJ} / \mathrm{mol}$. The stability of (rGO/ $\mathrm{Gr})_{2}$ electrode was also examined. The $\mathrm{rGO}$ coated electrode was a superior electrode for the indirect electro-oxidation process, giving enhanced colour removal (\%).
\end{abstract}

Keywords Graphene oxide · Reduced graphene oxide · Wastewater $\cdot$ Indirect electro-oxidation process

\section{Introduction}

Discharge of rinse water associated with industrial dyeing operations poses a serious challenge towards its efficient reclamation. Annually 280,000 tons dyes are discharged into water bodies worldwide, out of which around 8000 tons comprise of reactive dyes with extremely high colour fastness, chemical stability, and resistance towards oxidation. Several physico-chemical methods for treating dye wastewater are available; however, most of these systems seem to be plagued with low practical efficiency or low benefit-cost ratio. Common wastewater treatment techniques include adsorption [1], chemical coagulation [2], electrocoagulation [3], biological process [4], Fenton process [5], membrane filtration [6], and so on. But the issues of disposal of copious amounts of coloured sludge, membrane fouling, regeneration of spent adsorbents, equilibrium limitation, and many others render most of these processes unfeasible options. Another key problem with most of the approaches mentioned earlier is versatility for removing all classes of dyes. Adsorption suffers from expensive adsorbent regeneration, long treatment

\footnotetext{
$\triangle$ Kaushik Nath, drkaushiknath2013@gmail.com | ${ }^{1}$ Department of Chemical Engineering, Government Engineering College (Affiliated To Gujarat Technological University, Ahmedabad), Bharuch 392002, Gujarat, India. ${ }^{2}$ Department of Chemical Engineering, G.H.Patel College of Engineering \& Technology, Vallabh Vidyanagar 388120, Gujarat, India.
} 
time, and solid disposal issues, despite being effective for treating dye-containing effluent [7]. Chemical coagulation could attain a high removal efficiency, but it produces a large quantity of subsequent wastewater, which needs further treatment leading to overall high processing cost [8]. Fenton like processes and electrocoagulation produces a significant amount of sludge and is not effective for complete degradation of dye molecules. Membrane processes are capable of separation of almost all types of dyes from the effluent. There is no sludge formation, and the space requirement is also less. But the high cost of membrane and equipment, fouling problems during operation, are the limitations of the membrane process [9]. Biological treatment is economical, ineffective in the treatment of refractory organic wastewater [8]. Therefore, complete destruction of dye molecules from synthetic wastewater is an urgent need considering ecology and environmental damage prevention. It requires effective and eco-friendly techniques with high removal efficiency and low cost.

Of late electrochemical processes, particularly indirect electro-oxidation (EO) or direct anodic oxidation (DAO) process has drawn considerable attention for the reclamation of industrial wastewater [10, 11]. Electrochemical methods neither produce sludge nor require a substantial amount of chemicals. Additionally, the processes are operated at ambient conditions [12]. Adsorption of pollutants at the electrode surface, followed by their complete degradation into $\mathrm{CO}_{2}$ and $\mathrm{H}_{2} \mathrm{O}$ by electron transfer reaction, could be achieved in DAO [13]. On the other hand, in EO, a reactive oxidizing agent like $\mathrm{HOCl} / \mathrm{Cl}_{2}, \mathrm{H}_{2} \mathrm{O}_{2}$, and ozone generated in situ due to redox reaction tends to degrade the pollutant in bulk the solution [12].

The variety of processing parameters reported in the literature and the complexity of the mechanisms associated with electro-oxidation in dye wastewater treatment is yet scientifically elucidated. This underscores a very perceptible need for more research for an improved method, system, and apparatus for treating wastewater over the existing art. The material of construction, shape, and size of the electrodes constitutes a key research area in the electrooxidation process. The carbonaceous materials have been extensively studied for electro-oxidation methods due to their exceptional electrocatalytic activity, high chemical stability, and superior conductivity. Graphite electrodes are frequently used as anode and cathode electrode for their commercial availability, unique electrocatalytic activity, and nontoxicity to degrade dyes [14].

The graphite electrode surface can be modified to enhance electrical conductivity by different materials, metal-based oxides, polymers, and carbon-based materials [15-17]. Graphene oxide (GO) and reduced graphene oxide ( $\mathrm{rGO}$ ) are widely acknowledged as effective coating materials on account of their exceptional characteristics, such as high specific surface area, electric conductivity, and good chemical stability $[18,19]$. GO or rGO can be used as modification materials for electrochemical sensors [20-23]. However, a perusal of recent literature indicates that most of the research on $\mathrm{GO}$ or $\mathrm{rGO}$ coating over graphite electrode has been focused on Electro Fenton (EF) process, specifically decisive on cathode modification. Akerdi et al. [18] investigated the performance of the EF process using the $\mathrm{GO}$ and rGO coated Graphite electrode for decolourization of Methylene Blue (MB) and Acid Red 14 (AR14). Zhang et al. [24] demonstrated that graphene@graphite-based gas diffusion electrode (G-GDE) as an efficient and low-cost cathode material for the EF process. Bondarenko et al. [15] fabricated the $\mathrm{SnO}_{2} / \mathrm{rGO}$ composite film electrode shows high electrocatalytic activity for anodic oxidation of organic and inorganic substances. To the best of our knowledge, rGO modified graphite electrode as the anode is being reported for the first time to degrade the Reactive Turquoise Blue 21 (RTB21) from a model dye wastewater by the indirect electro-oxidation process. The RTB21 is widely used in the textile industry due to its unsurpassed qualities like incomparable stability, optimum solubility, and longer shelf life. It is difficult to degrade the RTB21 dye because of its highly stable aromatic structure. The discharge of RTB21 dye into water bodies from various textile industries becomes a grave concern due to their non-biodegradability, toxicity, and mutagenicity. Thus, it is damaging to the aesthetic value of the environment [25].

Keeping these into consideration, the present study aims at the facile synthesis of $\mathrm{rGO}$ coated electrode for the removal of RTB21 dye by the electro-oxidation process. GO was synthesized using improved Hummer's method. Firstly, $\mathrm{GO}$ was coated on a graphite electrode than reduced to $\mathrm{rGO}$ using the thermal method. The effect of process parameters such as initial $\mathrm{pH}$, current density, electrolyte concentration, and temperature on colour removal efficiency of dye was also studied using the graphite and rGO coated graphite electrode as anode and graphite electrode as the cathode. Besides, physical characterization was carried out by X-ray diffraction (XRD), Field emission scanning electron microscopy (FESEM), and contact angle (CA) techniques to study the electrode performance, as well as its stability. The work presented herein, although exploratory in nature, sought to provide new insights into wastewater treatment of the textile, dyestuff industry and to supplement the information on clean technology. 


\section{Materials and method}

\subsection{Chemicals and materials}

The textile dye Reactive Turquoise Blue 21, used in the present study, was procured from M/s Snehal Dye Chem. Ltd, Ankleshwar, Gujarat, India. The dye was used without any further treatment. The general characteristics of the dye are given in Table 1. All other chemicals (AR grade) were obtained from Merck, India and were used without any additional purification. Deionized (DI) water (conductivity $\sim 1 \mu \mathrm{S} / \mathrm{cm}$ ) was used during synthesis and other experiments. Natural Graphite flakes were purchased from Mass Graphite and Carbon Products, Gujarat, India. Graphite electrode $(3 \times 2 \times 0.20 \mathrm{~cm})$ was provided by Prime Industries, Maharashtra, India, and was used as a substrate for $\mathrm{GO}$ coating and electrode in the dye removal process.

\subsection{Synthesis of GO}

Graphite flakes were oxidized following improved Hummer's method to synthesize GO. $3.0 \mathrm{~g}$ of graphite flakes were added slowly to a mixture of $360 \mathrm{~mL}$ concentrated $\mathrm{H}_{2} \mathrm{SO}_{4}, 40 \mathrm{~mL} \mathrm{H}_{3} \mathrm{PO}_{4}$, and $19 \mathrm{~g} \mathrm{KMnO}_{4}$. During the mixing reaction, the temperature was kept below $20^{\circ} \mathrm{C}$. The reaction mixture was stirred for $12 \mathrm{~h}$ with heating at $50^{\circ} \mathrm{C}$. After cooling down to room temperature, the reaction mixture was poured into $400 \mathrm{~mL}$ ice followed by the addition of $2 \mathrm{~mL}, 30 \% \mathrm{H}_{2} \mathrm{O}_{2}$ to remove unreacted $\mathrm{KMnO}_{4}$. After filtration of the reaction mixture, the filtrate was centrifuged at $400 \mathrm{rpm}$ for $4 \mathrm{~h}$, and the supernatant was decanted away. The solid material obtained from the centrifugation process was washed with DI water, $30 \% \mathrm{HCl}$ and ethanol repeatedly for several times to remove dissolved impurities. The solid material was further centrifuged at $4000 \mathrm{rpm}$ for $4 \mathrm{~h}$, and the supernatant was decanted away. The remaining solid material was coagulated with $200 \mathrm{~mL}$ of ether. The suspension was filtered on Whatman paper, and the residue was dried at ambient temperature under vacuum condition. Finally, approximately $5.8 \mathrm{~g} \mathrm{GO}$ was obtained.

\subsection{Preparation of GO dispersion and rGO coating over graphite electrode}

To obtain homogenous suspension of GO in water, $0.1 \mathrm{~g}$ $\mathrm{GO}$ was added into $100 \mathrm{~mL}$ DI water followed by $3 \mathrm{~h}$ sonication ( $240 \mathrm{~W}$ ) with continuous stirring. Graphite electrode surfaces were pre-treated prior to coating. Pre-treatment was carried out by dipping the electrode into a dilute $\mathrm{HCl}$ solution for $2 \mathrm{~h}$, followed by sonication ( $130 \mathrm{~W}$ ) with acetone for $2 \mathrm{~h}$. Finally, it was rinsed with DI water and was dried at $60^{\circ} \mathrm{C}$ for $24 \mathrm{~h}$. The pre-treated graphite electrode, thus obtained, was denoted as raw $\mathrm{Gr}$. The dip-coating method was used for the coating of GO over the graphite substrate. The raw $\mathrm{Gr}$ was dipped into a homogeneous suspension of $\mathrm{GO}$ under the continuous stirring condition for 3-5 s and dried for $30 \mathrm{~min}$ at $110^{\circ} \mathrm{C}$ in a hot air oven. This dipping cycle was repeated several times to ensure a significant coating of GO over raw Gr. Three sets of anode electrodes, namely uncoated $\mathrm{Gr}$ : $(\mathrm{Gr})_{0}$, $\mathrm{Gr}$ with 10 cycles of $\mathrm{GO}$ coating: (GO/Gr) ${ }_{1}$ and $\mathrm{Gr}$ with 20 cycles of $\mathrm{GO}$ coating: $(\mathrm{GO} / \mathrm{Gr})_{2}$ were selected for the present study. GO reduction was carried out by the thermal reduction method. $\mathrm{GO} / \mathrm{Gr}$ electrode was placed into the tubular furnace at $450{ }^{\circ} \mathrm{C}$ for $60 \mathrm{~min}$. These electrodes were designated as $(\mathrm{Gr})_{0},(\mathrm{rGO} /$ $\mathrm{Gr})_{1},(\mathrm{rGO} / \mathrm{Gr})_{2}$. Chemical structures of graphite, $\mathrm{GO}, \mathrm{rGO}$ are presented in Fig. 1.

\subsection{Electrochemical experiments}

The indirect electro-oxidation process for the decolourization of RTB21 wastewater was carried out in an electrochemical cell schematically represented in Fig. 2 . The electrochemical cell was made up of $250 \mathrm{~mL}$ cylindrical glass vessel. A total of $250 \mathrm{~mL}$ of RTB21 dye wastewater was taken for each set of experiments, and the same was carried out in

Table 1 Characteristics of treated dye

\begin{tabular}{lllll}
\hline Chemical structure & Molecular formula & Colour index name & $\lambda_{\text {max }}(\mathrm{nm})$ & Molecular weight $(\mathrm{g} / \mathrm{mol})$ \\
\hline & $\mathrm{C}_{40} \mathrm{H}_{25} \mathrm{CuN}_{9} \mathrm{O}_{14} \mathrm{~S}_{5}$ & C.I. Reactive Blue 21 & 624 & 1159.62 \\
\hline
\end{tabular}



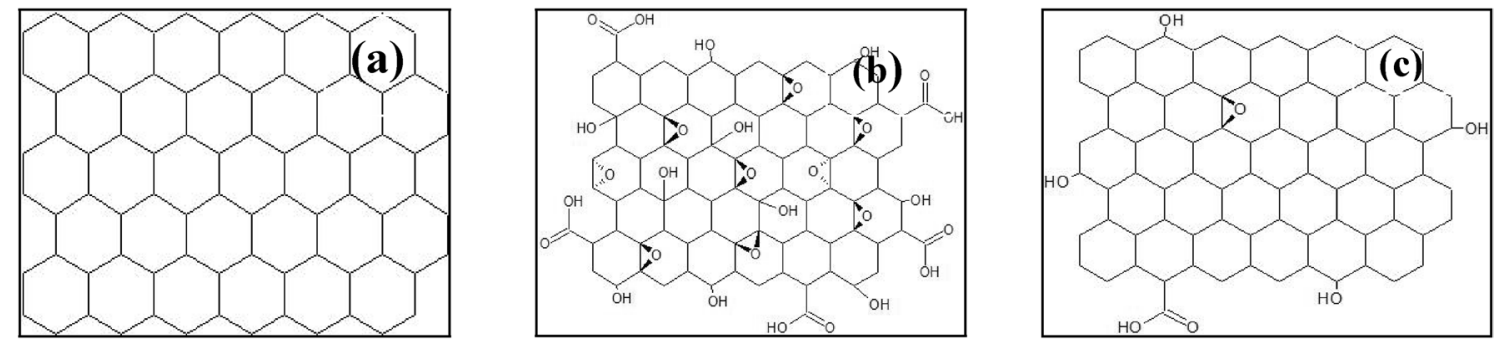

Fig. 1 Chemical structure of graphite (a), GO (b), rGO (c)

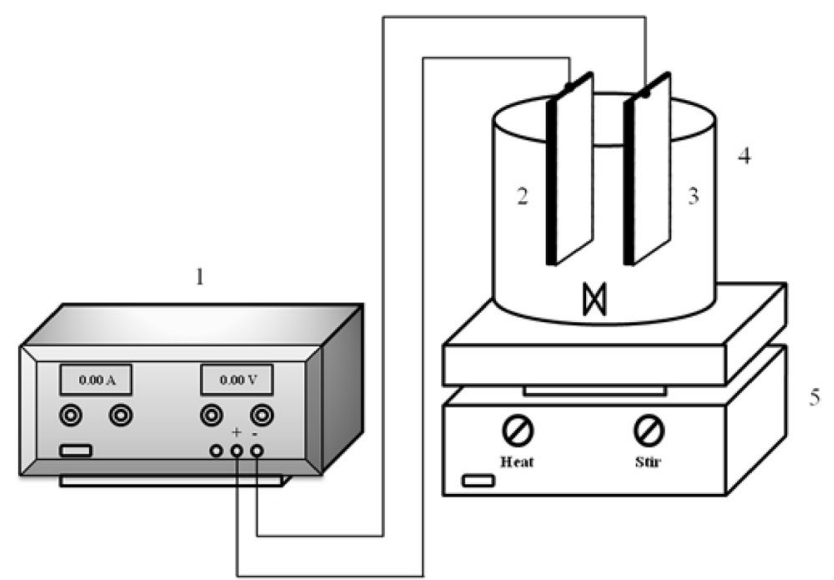

Fig. 2 Schematic diagram of the experimental set-up: (1) DC Power Supply, (2) Anode electrode, (3) Cathode electrode, (4) Electrochemical cell, (5) Magnetic stirrer

batch operation, continuously stirred by the magnetic stirrer at $800 \mathrm{rpm}$. Two plates of the electrode were used as anode and cathode for the electrochemical process. The anode was configured in a monopolar connection mode with cathode with an inter-electrode gap of $1 \mathrm{~cm}$ between the two plates. The effective area of the anode electrode was estimated to be $10 \mathrm{~cm}^{2}$. Initial $\mathrm{pH}$ of the solution was adjusted by adding $0.1 \mathrm{M} \mathrm{H}_{2} \mathrm{SO}_{4}$ or $0.1 \mathrm{M} \mathrm{NaOH}$ and was measured by a digital pH meter (El, Model no 112). A predetermined amount of $\mathrm{NaCl}$ was added to improve the conductivity before the Direct current (DC) supplied. The conductivity of the samples was measured by a digital conductivity meter (El, model no. $651)$. The required current density $\left(\mathrm{A} / \mathrm{m}^{2}\right)$ was adjusted by regulating the voltage of $D C$ regulated power supply (Make: SIGMA, 0-30 V 0-5 A). The colour removal efficiency of the sample collected at various time intervals was calculated using Eq. 1:

Colour removal $(\%)=\left(1-\frac{A}{A_{0}}\right) \times 100$ where, $A_{0}$ and $A$ are the light absorbance of a sample before and after the electrochemical process, respectively, measured using a UV/VIS spectrophotometer (Model $\mathrm{CL}$ 335). The electrical energy consumption $\left(C_{\text {energy' }} \mathrm{kWh} / \mathrm{m}^{3}\right)$ for the EO process was determined according to Eq. 2 [26]:

$C_{\text {energy }}=\frac{\left(U i_{\mathrm{EO}}\right)}{v}$

where $U$ is the average cell voltage $(\mathrm{V}), i$ is the current $(\mathrm{A})$, $t_{\mathrm{EO}}$ is the processing time $(\mathrm{h})$, and $v$ is the volume of the solution $\left(\mathrm{m}^{3}\right)$. The current efficiency (CE) for the EO process was calculated using Eq. (3) [27].

$\mathrm{CE}(\%)=\frac{3.6 n F v \Delta C}{i t_{\mathrm{EO}}} \times 100$

where $n$ is the number of exchanged electrons, $F$ is Faraday's constant $(96,487 \mathrm{C} / \mathrm{mol}), \Delta C$ is the concentration difference of dye (mol/L). Samples collected at various time intervals were filtered through Whatman filter paper to remove the unwanted particulate matter present in a sample. RTB21 removal was studied by varying the specific parameter, keeping the other parameters constant, and the effect of various vital parameters was obtained. After each run, electrodes were washed by $0.1 \mathrm{M} \mathrm{HCl}$ solution to remove the organic impurities and oxide layer from electrodes and then dried for reuse.

The kinetic parameter for the EO process can be described by the Arrhenius equation as follows:

$K_{1}=A e^{\left(-\frac{E_{\mathrm{a}}}{R T}\right)}$

where $K_{1}$ is the rate constant, $A$ is the Arrhenius constant, $E_{\mathrm{a}}$ is apparent activation energy $(\mathrm{kJ} / \mathrm{mol}), R$ is the ideal gas constant $(0.0083 \mathrm{~kJ} / \mathrm{mol} \mathrm{K})$, and $T$ is the Temperature $(\mathrm{K})$.

\subsection{Characterization of rGO coating over graphite}

The organic functional groups (chemical bonds) present in the sample were identified by the Fourier transform infrared spectroscopy (FTIR, Make: Shimadzu, IRPrestige-21). 
The spectral outputs were recorded in the transmittance mode at the mid-infrared region of $4000-400 \mathrm{~cm}^{-1}$ as a function of wavenumber at a resolution of $4.0 \mathrm{~cm}^{-1}$ with an acquisition time of $1 \mathrm{~min}$. The samples were kept under constant nitrogen flow at a rate of $10 \mathrm{~mL} \mathrm{~min}^{-1}$ to eliminate undesired absorbance by surrounding moisture and carbon dioxide. The electrodes' surface morphology was studied by field emission scanning electron microscopy (FE-SEM, Make: ESEM EDAX XL-30, Philips, Netherlands) at $10 \mathrm{kV}$. The diffraction patterns and the crystallinity of the synthesized materials were examined by D8 Advanced (Bruk, Germany) diffractometer with $\mathrm{Cu}$ Ka radiation $(\lambda=1.54 \AA)$ in the range $5^{\circ} \leq 2 \theta \leq 85^{\circ}$. The $X$-ray generator (X-ray power $2 \mathrm{~kW}$; detector: $X e-$ filled counterate) was operated at an excitation voltage of $45 \mathrm{kV}$ and a current of $40 \mathrm{~mA}$. The contact angle of water on synthesized material was examined by a contact angle meter Biolin Scientific (Model: Attention (Biolin Scientific) Theta). A 5- $\mu$ L liquid was dropped using a micropipette on the material surface at room temperature.

\section{Results and discussion}

To accomplish a high level of efficiency for decolourization of RTB21 dye by EO process, several factors to be considered into accounts such as initial $\mathrm{pH}$, current density (A/ $\left.\mathrm{m}^{2}\right), \mathrm{NaCl}$ as an electrolyte concentration $(\mathrm{g} / \mathrm{L})$, and temperature $\left({ }^{\circ} \mathrm{C}\right)$. Optimum values find out to achieve a higher degree of decolourization considering all the experimental conditions.

\subsection{Effect of initial pH}

Initial pH plays a vital role in the performance of the EO process and is considered as one of the essential process parameters [28]. Thus, it is worthwhile to analyse the effect of the initial $\mathrm{pH}$ of feed solution on the colour removal efficiency in the presence of $\mathrm{Gr}$ and $\mathrm{rGO}$ coated $\mathrm{Gr}$ electrodes. In this work, the effect of the different initial $\mathrm{pH}(3.0-11.0)$ at process time $15 \mathrm{~min}$ for treatment of $50 \mathrm{ppm}$ synthetic RTB21 wastewater was studied at $2 \mathrm{~g} / \mathrm{L} \mathrm{NaCl}, 200 \mathrm{~A} / \mathrm{m}^{2}$ current density, and $30^{\circ} \mathrm{C}$ temperature. At acidic condition $(3.0 \mathrm{pH})$, per cent colour removal was found to be 41.77, 54.11 , and 62.17 for $(\mathrm{Gr})_{0},(\mathrm{rGO} / \mathrm{Gr})_{1},(\mathrm{rGO} / \mathrm{Gr})_{2}$, respectively. At neutral $\mathrm{pH}$, it was observed to be $73.37,82.00$, and 96.69 for $(\mathrm{Gr})_{0},(\mathrm{rGO} / \mathrm{Gr})_{1}$, and $(\mathrm{rGO} / \mathrm{Gr})_{2}$, respectively. Under the basic conditions, it was reduced compared to the neutral condition. Figure 3 presents the effect of initial $\mathrm{pH}$ on the experimental results of colour removal efficiency. However, the formation of active chlorine as a dominant oxidizing agent via the oxidation process at the anode could

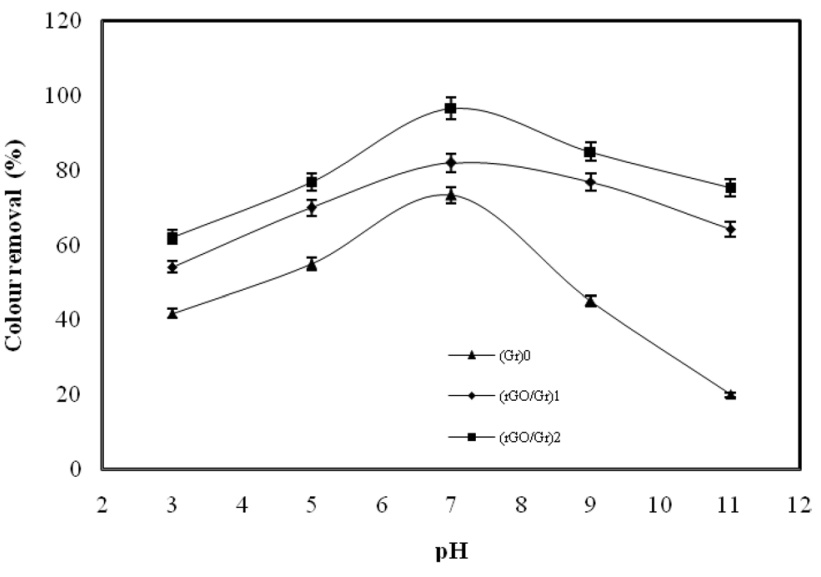

Fig. 3 Effect of Initial pH on colour removal (\%) at constant 50 ppm dye concentration, $200 \mathrm{~A} / \mathrm{m}^{2}$ current density, $2.0 \mathrm{~g} / \mathrm{L} \mathrm{NaCl}$ concentration, $30^{\circ} \mathrm{C}$ temperature, and 15 min process time

lead to the decolourization of RTB21 dye, which would be further reduced to $\mathrm{HOCl}$ or $\mathrm{OCl}^{-}$[29].

In acidic conditions, relatively low stability the hypochlorous acid $(\mathrm{HOCl})$ might be responsible for the reduced decolourization as $\mathrm{HOCl}$ possesses higher oxidation power $(1.49 \mathrm{~V})$ than that of $\mathrm{OCl}^{-}(0.94 \mathrm{~V})$. On the other hand, in basic condition, chlorate or perchlorate productions from $\mathrm{Cl}_{2} / \mathrm{HOCl}$ could lead to lower decolourization of RTB21 dye [13, 30], as shown by the chemical reactions (5) and (6):

$6 \mathrm{HOCl}+3 \mathrm{H}_{2} \mathrm{O} \rightarrow 2 \mathrm{ClO}_{3}^{-}+4 \mathrm{Cl}^{-}+12 \mathrm{H}^{+}+\frac{3}{2} \mathrm{O}_{2}+6 \mathrm{e}^{-}$

$\mathrm{ClO}_{3}^{-}+\mathrm{H}_{2} \mathrm{O} \rightarrow \mathrm{ClO}_{4}^{-}+2 \mathrm{H}^{+}+2 \mathrm{e}^{-}$

These results are in line with those obtained by Kariyajjanavar et al. [31] and Rajkumar and Mathkumar [29].

\subsection{Effect of current density}

The reaction mechanism of EO is greatly influenced by current density - one of the most essential electrochemical process parameter. To analyse the effect of current density on the EO process of the present study, the current density in the range of $100-300 \mathrm{~A} / \mathrm{m}^{2}$ was applied by keeping other parameters constant at 7.0 initial $\mathrm{pH}$, $30{ }^{\circ} \mathrm{C}$ temperature, $2 \mathrm{~g} / \mathrm{L} \mathrm{NaCl}$, and $50 \mathrm{ppm}$ synthetic RTB21 wastewater. Colour removal efficiency as a function of current density is presented in Fig. 4a. A perusal of Fig. 4 a, reveals that the extent of colour removal efficiency increased with the increase in current density for all three electrodes. In the case of $(\mathrm{Gr})_{0}$ electrode, the maximum per cent removal of colour was estimated to be $77.78 \%$, while the same for $(\mathrm{rGO} / \mathrm{Gr})_{1}$ and $(\mathrm{rGO} / \mathrm{Gr})_{2}$ 
Fig. 4 Effect of current density $\left(\mathrm{A} / \mathrm{m}^{2}\right)$ on colour removal (\%) (a), current efficiency (\%) (b) at constant $50 \mathrm{ppm}$ dye concentration, 7.0 initial $\mathrm{pH}$, $2.0 \mathrm{~g} / \mathrm{L} \mathrm{NaCl}$ concentration, $30^{\circ} \mathrm{C}$ temperature, and $15 \mathrm{~min}$ process time
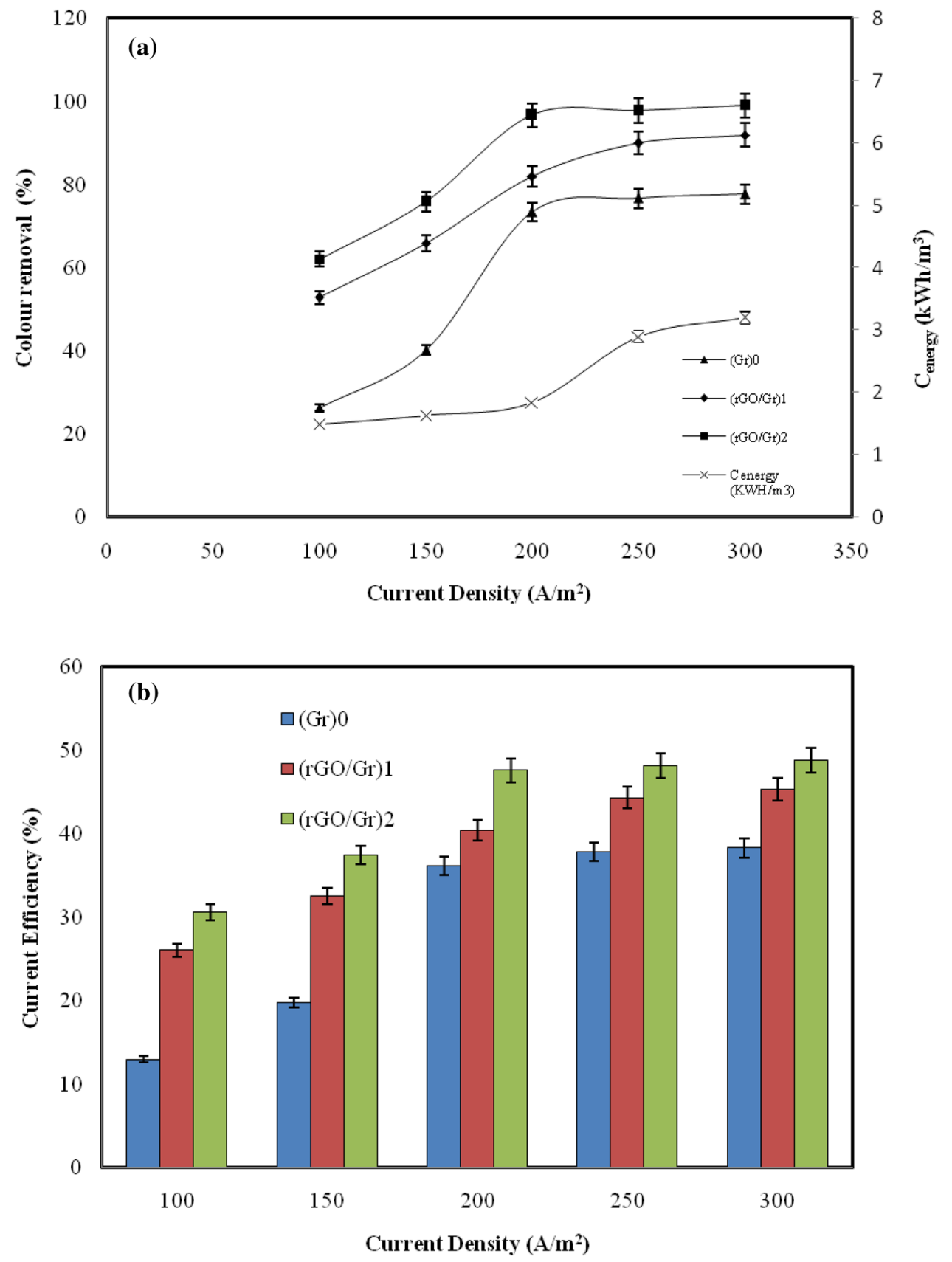

electrodes were $91.98 \%$ and $99 \%$, respectively, at the current density of $300 \mathrm{~A} / \mathrm{m}^{2}$. During the processing time of $15 \mathrm{~min}$, electrical energy consumption increased from 1.5 to $3.2 \mathrm{kWh} / \mathrm{m}^{3}$. The per cent colour removal (\%) could thus be improved by increasing the current density. It is worthwhile to note that as the current density was increased from 100 to $300 \mathrm{~A} / \mathrm{m}^{2}$, the rate of generation of an oxidizing agent increased as well due to anodic oxidation thereby resulting in an improvement of the system efficiency [31, 32]. The relation between current efficiency and current density is presented in Fig. $4 \mathrm{~b}$ for all the three-electrode systems used in the present study. The results indicate that the current efficiency was almost constant after $200 \mathrm{~A} / \mathrm{m}^{2}$ irrespective of the nature of the graphite electrodes. However, it is imperative to mention that above $200 \mathrm{~A} / \mathrm{m}^{2}$, no significant changes in the colour removal (\%) could be achieved. It was plausibly because a part of the current devoured into an oxygen evolution reaction, besides oxidation of pollutants [33]. Hence, this was considered to be an optimum value for further experiments. 


\subsection{Effect of electrolyte concentration}

A supporting electrolyte is added to the solution to improve the conductivity of the solution. The addition of electrolyte results in the reduction of electrical energy consumption and the ohmic drop. In the present work, $\mathrm{NaCl}$ was added as an electrolyte to improve the conductivity of the RTB21 wastewater to enhance the electron transfer rate between electrodes, thereby resulting in an enhancement in the decolourization of RTB21 dye. The experiments were conducted to determine the effect of $\mathrm{NaCl}$ concentration on the colour removal efficiency by EO process, for $50 \mathrm{ppm}$ synthetic RTB21 wastewater in the range of $1-3 \mathrm{~g} / \mathrm{L} \mathrm{NaCl}$ concentration for 15 min keeping current density, initial $\mathrm{pH}$, and temperature constant at $200 \mathrm{~A} / \mathrm{m}^{2}, 7.0$ and $30^{\circ} \mathrm{C}$, respectively, for all three electrodes used in the present study. The results are presented in Fig. 5. It reveals that the per cent colour removal of dyes for all the three-electrode systems increased with increasing $\mathrm{NaCl}$ concentration.

Moreover, it is observed that when $\mathrm{NaCl}$ concentration increased from 1 to $3 \mathrm{~g} / \mathrm{L}$, colour removal (\%) achieved about 74.81, 85.00, and 97.37 for $(\mathrm{Gr})_{0},(\mathrm{rGO} / \mathrm{Gr})_{1},(\mathrm{rGO} /$ $\mathrm{Gr})_{2}$, respectively. Besides, the conductivity of the solution increased significantly from 1452 to $3614 \mu \mathrm{S} / \mathrm{cm}$, resulting in a reduction of the operating voltage from 18.1 to $7.1 \mathrm{~V}$. Consequently, the electrical energy consumption reduced from 3.62 to $1.42 \mathrm{kWh} / \mathrm{m}^{3}$, and the electro-oxidation process was promoted by producing active chlorine at anode [30]. The mechanistic equations for the indirect electro-oxidation process are presented in Eq. (7-11) [12, 34],

At Anode $: 2 \mathrm{Cl}^{-} \rightarrow \mathrm{Cl}_{2}+2 \mathrm{e}^{-}$

At Cathode $: 2 \mathrm{H}_{2} \mathrm{O}+2 \mathrm{e}^{-} \rightarrow \mathrm{H}_{2}+2 \mathrm{OH}^{-}$
In Bulk of the Solution:

$\mathrm{Cl}_{2}+\mathrm{H}_{2} \mathrm{O} \leftrightarrow \mathrm{HOCl}+\mathrm{H}^{+}+\mathrm{Cl}^{-}$

$\mathrm{HOCl} \leftrightarrow \mathrm{H}^{+}+\mathrm{OCl}^{-}$

Dye $+\mathrm{OCl}^{-}$or $\mathrm{HOCl} \cdots \rightarrow$ Dye intermediate $\cdots \rightarrow \mathrm{CO}_{2}+\mathrm{H}_{2} \mathrm{O}+\mathrm{Cl}^{-}$

Enhancement in the $\mathrm{NaCl}$ concentration up to $2 \mathrm{~g} / \mathrm{L}$ led to an increase in the extent of decolourization, and the same was almost 73.37, 82.00, and $96.69(\%)$ for $(\mathrm{Gr})_{0}$, $(\mathrm{rGO} / \mathrm{Gr})_{1},(\mathrm{rGO} / \mathrm{Gr})_{2}$, respectively. This could be due to the generation of a more oxidizing agent such as $\mathrm{Cl}_{2}, \mathrm{HOCl}$, $\mathrm{OCl}^{-}[13]$ in the process. Therefore, $2 \mathrm{~g} / \mathrm{L} \mathrm{NaCl}$ concentration was considered to be optimal for successive degradation experiments.

\subsection{Effect of temperature and thermodynamic study}

The effect of temperature for $50 \mathrm{ppm}$ synthetic RTB21 wastewater on colour removal (\%) for the EO process was studied at four different temperatures $\left(20,30,40,50^{\circ} \mathrm{C}\right)$ for all the three types of electrode keeping the other parameters (duration: $15 \mathrm{~min}$; current density: $200 \mathrm{~A} / \mathrm{m}^{2}$; initial $\mathrm{pH}$ : 7.0, and $\mathrm{NaCl}$ concentration: $2 \mathrm{~g} / \mathrm{L}$ ) constant. As presented in Fig. 6 , the results indicate that per cent colour removal increased with increase in temperature. It was observed that the per cent colour removal observed in $(\mathrm{rGO} / \mathrm{Gr})_{2}$ electrode was higher than its two other counterparts. An increase in temperature could enhance the reaction rate between oxidants and dye, facilitating colour removal (\%) in the EO process. But the high temperature could also enhance the decomposition rate of oxidants [35].
Fig. 5 Effect of $\mathrm{NaCl}$ concentration $(\mathrm{g} / \mathrm{L})$ on colour removal (\%) at constant $50 \mathrm{ppm}$ dye concentration, 7.0 initial $\mathrm{pH}$, $200 \mathrm{~A} / \mathrm{m}^{2}$ current density, $30{ }^{\circ} \mathrm{C}$ temperature, and $15 \mathrm{~min}$ process time

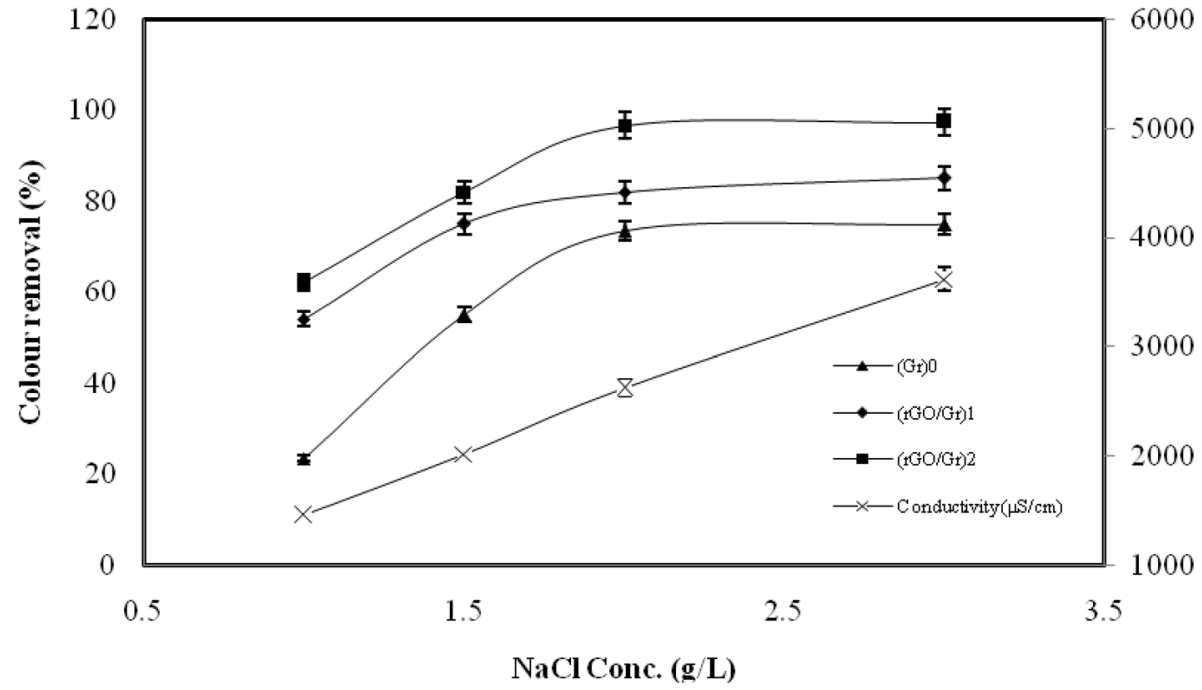

SN Applied Sciences 


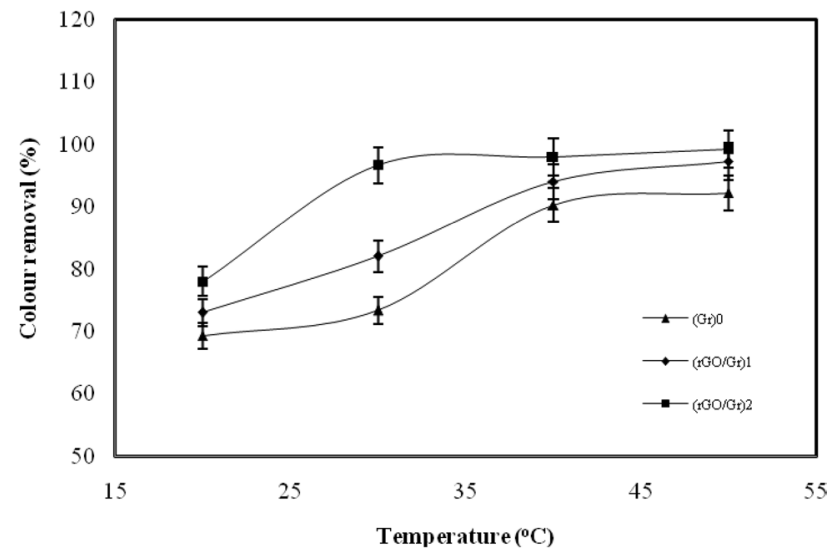

Fig. 6 Effect of Temperature $\left({ }^{\circ} \mathrm{C}\right)$ on colour removal (\%) at constant $50 \mathrm{ppm}$ dye concentration, 7.0 initial $\mathrm{pH}, 200 \mathrm{~A} / \mathrm{m}^{2}$ current density, $2.0 \mathrm{~g} / \mathrm{L} \mathrm{NaCl}$ concentration, and 15 min process time

Therefore, the experiment temperature condition should not be kept too high. Similar observations are reported by Duan et al. [35]. The colour removal rate depends on dye concentration and the concentration of chlorine/ hypochlorite. Therefore, the kinetics of colour removal was studied following Eq. (12)

$\mathrm{d}\left[C_{t}\right] / \mathrm{d} t=k\left[C_{t}\right]\left[C I_{2}\right]$

where $C_{t}$ is the concentration of RTB21 dye at time $t, k$ is the first-order rate constant. In the EO process, chloride from wastewater gets converted into chlorine/hypochlorite. Oxidation of dye is carried out by chlorine/hypochlorite, the bulk solution, and then it is reduced back to chloride ion $[30,36]$. Catalytically, the EO process repeats its behaviour. Therefore, during the experimental run, the concentration of chlorine/hypochlorite was assumed to be constant. Accordingly, Eq. (12) could be modified by a pseudo-first-order kinetic equation is as shown in Eqs. (13) and (14),

$\mathrm{d}\left[C_{t}\right] / \mathrm{d} t=K_{1}\left[C_{t}\right]$

$\ln \left(\frac{C_{t}}{C_{0}}\right)=-K_{1} t$

where $C_{0}$ is the initial dye concentration, $K_{1}$ is the apparent pseudo-first-order rate constant. The rate constant $K_{1}$, $\mathrm{min}^{-1}$, and respective $R^{2}$ value obtained from the slope of the plot of $\ln \left(C_{t} / C_{0}\right)$ versus time, shown in Table 2.

The Arrhenius plot of $\ln \left(K_{1}\right)$ versus $1 / T$ provides good linearity with a coefficient of determination $\left(R^{2}=0.9659\right)$, which validates the pseudo-first-order kinetics presented in Fig. 7. The activation energy $\left(E_{\mathrm{a}}\right)$ and Arrhenius constant
Table 2 Pseudo-first-order kinetic data

\begin{tabular}{lllll}
\hline Temperature $\left({ }^{\circ} \mathrm{C}\right)$ & 20 & 30 & 40 & 50 \\
\hline$K_{1}\left(\mathrm{~min}^{-1}\right)$ & 0.130 & 0.238 & 0.263 & 0.310 \\
$R^{2}$ & 0.928 & 0.968 & 0.99 & 0.988 \\
\hline
\end{tabular}

(A) value, calculated and noted from the plot $\ln \left(K_{1}\right)$ versus $1 / T$ were found to be $23.42 \mathrm{~kJ} / \mathrm{mol}$ and 2022.32 , respectively. The comparative studies of previously reported reaction kinetic constants for the electrochemical\& RTB21 removal processes are listed in Table 3 . The activation energy mainly depends on the nature of the reaction. The small value of $E_{\mathrm{a}}$ indicates a fast reaction. It is reported in the literature that, for homogeneous diffusion-controlled response $E_{\mathrm{a}}<40 \mathrm{~kJ} / \mathrm{mol}$, typically in the range of $20 \mathrm{~kJ} / \mathrm{mol}$ [37-39]. Therefore, the EO process for colour removal of RTB21 in aqueous medium using $(\mathrm{rGO} / \mathrm{Gr})_{2}$ was more likely of a diffusion-controlled reaction.

\subsection{FTIR analysis}

Figure 8 represents the FTIR spectrum of graphite powder, GO, rGO. Significant peaks, indicating several functional groups are almost absent in the FTIR spectrum of graphite powder. Only $\mathrm{C}-\mathrm{H}$ bonds exist at the carbon edges, but in negligible amounts compared to the amounts of $C-C / C=C$ bonds in bulk. A few weak bands can be assigned to adsorbed water molecules. This indicates the chemical inertness of graphite as a bulk material [40].

On the other hand, a perusal of the FTIR spectra of GO indicates the presence of several oxygen-derived species; functional groups in its structure. A highly intense

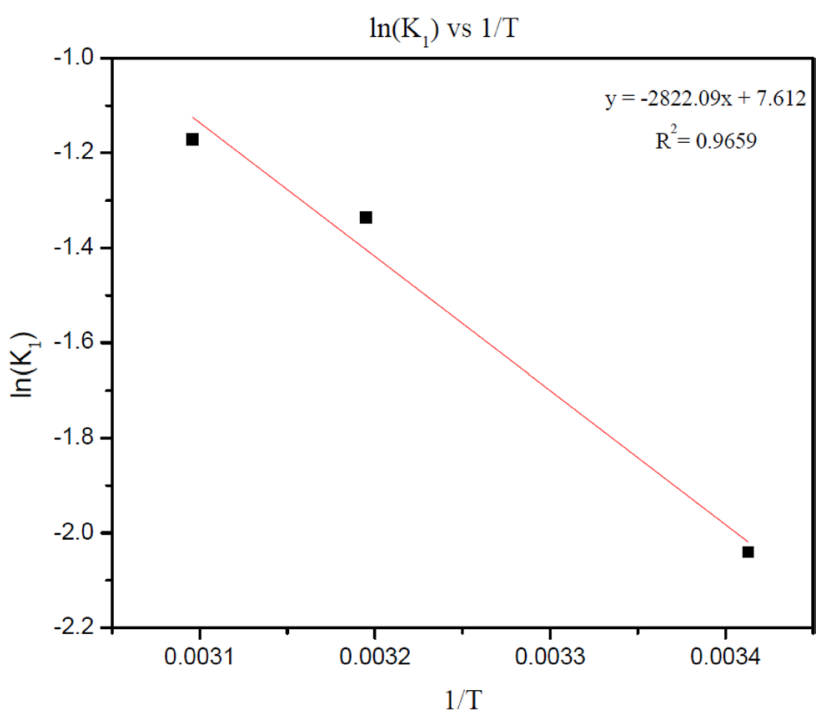

Fig. 7 Plot of $\ln \left(K_{1}\right)$ Vs $1 / T$ 
Table 3 Comparative study of previously reported reaction kinetic constants for electrochemical \& RTB21 removal processes

\begin{tabular}{|c|c|c|c|c|c|c|}
\hline Wastewater & $\begin{array}{l}\text { Treatment process } \\
\text { (Electrode) }\end{array}$ & $\begin{array}{l}\text { Reaction } \\
\text { order (a) }\end{array}$ & Rate constant $(k)$ & $E$ & $A$ & References \\
\hline RTB21 & $\begin{array}{l}\text { Indirect Electro-oxida- } \\
\text { tion Process (rGO/ } \\
\text { graphite) }\end{array}$ & $1(p)$ & $0.13-0.31 \mathrm{~min}^{-1}$ & $23.42 \mathrm{~kJ} / \mathrm{mol}$ & 2022.32 & Present study \\
\hline 4-Chloroguaiacol (4-CG) & $\begin{array}{l}\text { Electrochemical oxida- } \\
\text { tion }\left(\mathrm{Nb} / \mathrm{PbO}_{2}\right)\end{array}$ & $1(p)$ & $1.78-4.62 \mathrm{~h}^{-1}$ & $15 \mathrm{~kJ} / \mathrm{mol}$ & - & [37] \\
\hline Bilgewater & Electrochemical (Pt/lr) & 1 & $6.775 \times 10^{-2} \mathrm{~min}^{-1}$ & $26.2 \mathrm{~kJ} / \mathrm{mol}$ & $1943.0 \mathrm{~min}^{-1}$ & {$[38]$} \\
\hline Phenol & Electrocatalytic $\left(\beta-\mathrm{PbO}_{2}\right)$ & $1(p)$ & $0.303-1.663\left(10^{3} \mathrm{~S}^{-1}\right)$ & $23.8 \mathrm{~kJ} \mathrm{~mol}^{-1}$ & - & [39] \\
\hline $\begin{array}{l}\text { Beet sugar factory } \\
\text { wastewater }\end{array}$ & Electrocoagulation (Iron) & 1.2 & $0.057 \mathrm{~L}^{0.2} /\left(\mathrm{g}^{0.2} \mathrm{~h}\right)$ & $5.17 \mathrm{~kJ} / \mathrm{mol}$ & $0.36 \mathrm{~L}^{0.2} /\left(\mathrm{g}^{0.2} \mathrm{~h}\right)$ & {$[45]$} \\
\hline $\begin{array}{l}\text { Resorcinol in the aque- } \\
\text { ous medium }\end{array}$ & $\begin{array}{l}\text { Electrochemical oxida- } \\
\text { tion (Boron-Doped } \\
\text { Diamond Anode) }\end{array}$ & 1 & $0.0145 \mathrm{~min}^{-1}$ & $5.32 \mathrm{~kJ} / \mathrm{mol}$ and & $0.1169 \mathrm{~min}^{-1}$ & {$[46]$} \\
\hline RTB 21 & $\begin{array}{l}\text { Solar based Photocata- } \\
\text { lytic }\end{array}$ & $1(p)$ & $0.0199 \mathrm{~min}^{-1}$ & - & - & [47] \\
\hline RTB21 & Photocatalytic & $1(p)$ & $\begin{array}{l}0.0258 \mathrm{~min}^{-1} \text { (for } \mathrm{Nb}- \\
\mathrm{TiO} 2 \text { ) and } 0.0225 \mathrm{~min}^{-1} \\
\text { (for Fe: } \mathrm{Nb}-\mathrm{TiO} 2 \text { ) }\end{array}$ & - & - & {$[48]$} \\
\hline RTB21 & $\begin{array}{l}\text { Pd-catalyzed } \mathrm{H}_{2} \text { Reduc- } \\
\text { tion }\end{array}$ & $1(p)$ & $0.179 \pm 0.009 \mathrm{~d}^{-1}$ & - & - & [49] \\
\hline RTB21 & Adsorption & $2(p)$ & $1.95-6.32 \mathrm{mg} \mathrm{g}^{-1} \mathrm{~min}^{-1}$ & - & - & [50] \\
\hline
\end{tabular}

(p): pseudo order

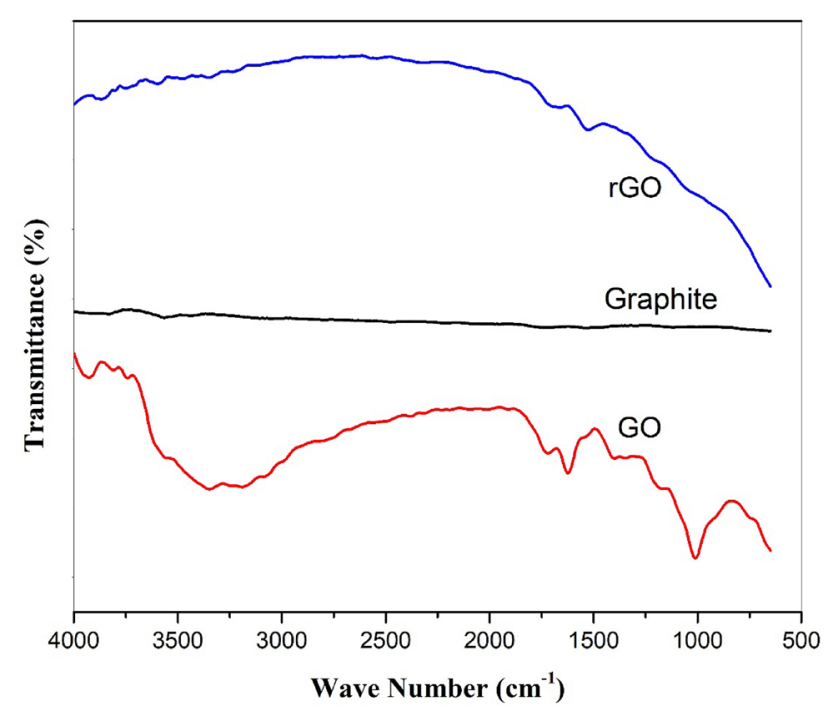

Fig. 8 FTIR spectra of graphite powder, GO, and rGO

and broad absorption peak at $3350(2400-3600) \mathrm{cm}^{-1}$, which corresponds to the $\mathrm{O}-\mathrm{H}$ stretching vibration, implying the presence of $\mathrm{COOH}$ and/or $\mathrm{OH}$ functional groups. The bands at $1720,1631 \mathrm{~cm}^{-1}$ corresponding to $C=0$ stretching (carbonyl group), and $C=C$ stretching, respectively. The bands at 1398 and $1010 \mathrm{~cm}^{-1}$ can be assigned to $\mathrm{C}-\mathrm{O}-\mathrm{C}$ (epoxide group) stretching and $\mathrm{C}-\mathrm{O}$ stretching (epoxy group), respectively [18]. In essence, the FTIR results confirmed various oxygen-containing functional groups like hydroxyl, carbonyl, and epoxy, indicating the effective synthesis of GO under present experimental conditions [40]. The FTIR spectra of $\mathrm{rGO}$ indicate the absence or weak peaks of oxygenated groups at rGO sheets [18].

\subsection{XRD analysis}

To analyse the crystallinity of the graphite powder, GO and rGO, the XRD patterns were analysed as shown in Fig. 9. The XRD of the graphite powder shows the presence of sharp and robust peak at $2 \theta=26.53^{\circ}$ and low-intensity peak at $2 \theta=54.5$, which corresponds to (002) and (004) $\mathrm{hkl}$ plane, respectively. It shows high crystallinity of graphite with crystallite size $34.65 \mathrm{~nm}$ at $26.53^{\circ}$, calculated by Scherrer's formula [40]. The interlayer spacing was found to be $0.336 \mathrm{~nm}$, calculated by the Bragg's law. For GO, XRD patterns show a peak at $2 \theta=11.1^{\circ}$ having a hkl plane at (001) with crystallite size $5.17 \mathrm{~nm}$, the interlayer spacing of $0.796 \mathrm{~nm}$. The interlayer spacing of GO increased by $136 \%$ compared to graphite power because of oxygenated functional groups present in GO [41]. Almost $85 \%$ crystallite size of $\mathrm{GO}$ was reduced compared to graphite powder. In the XRD of the $(\mathrm{rGO} / \mathrm{Gr})_{2}$, electrode surface shows the characteristic peak of $\mathrm{rGO}$ at $2 \theta=26.67^{\circ}$ having a hkl plane at (002) with crystallite size of $17.5 \mathrm{~nm}$ and interlayer spacing of $0.334 \mathrm{~nm}$, this was noted for the presence of rGO over graphite surface [18]. The XRD of the used ( $\mathrm{rGO}$ / 
Fig. 9 Wide-angle X-ray diffraction pattern of the graphite flakes, GO power, and ( $\mathrm{rGO}$ / $\mathrm{Gr})_{2}$ electrode, and used ( $\mathrm{rGO} /$ Gr) ${ }_{2}$ electrode

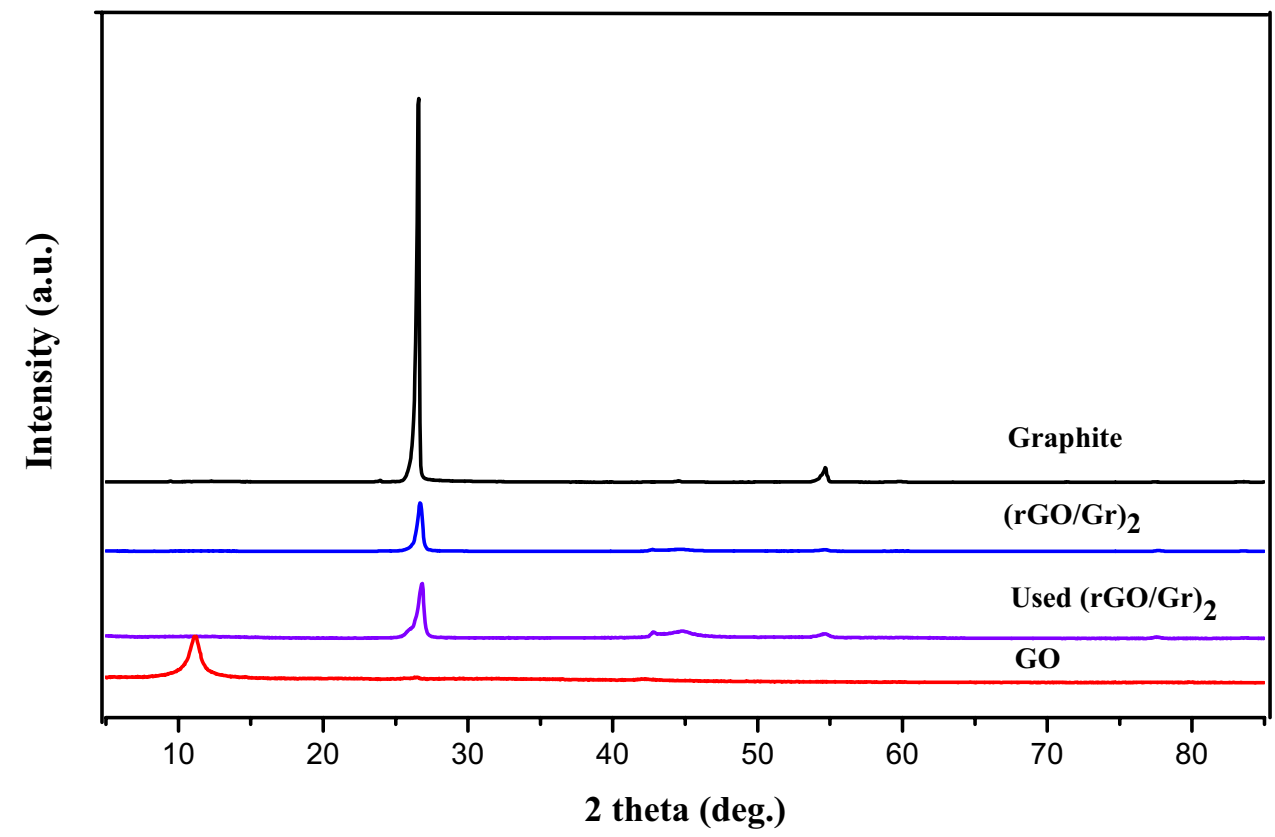

$\mathrm{Gr})_{2}$ electrode surface after 5 runs shows the characteristic peak of rGO at $2 \theta=26.74^{\circ}$ with a crystallite size of $14.5 \mathrm{~nm}$ and interlayer spacing of $0.333 \mathrm{~nm}$. This indicates good stability of $\mathrm{rGO}$ coating over the graphite surface, and it is not leached out into solution.

\subsection{FESEM analysis}

The morphology of the (a) graphite powder, (b) GO powder, (c) graphite electrode (Gr), (d, e) rGO coated $\mathrm{Gr},(\mathrm{f}) \mathrm{C} / \mathrm{S}$ of $r G O$ coated $\mathrm{Gr}$ is illustrated in Fig. 10. The SEM images show the respective sample's surface structures, the synthesized material, and the successful thin coating of $\mathrm{rGO}$ over Gr. Stacked layer type structure of graphite powder shown in Fig. 10a. Randomly wrinkled nanosheets of a few micrometer sizes of $G O$ is shown in Fig. 10b, strongly associated with each other by $\pi-\pi$ bonds [18]. The FESEM image of the graphite electrode (Fig. 10c) shows the porous structure with a little minor irregularity over the smooth surface significant to a low surface area. From Fig. $10 \mathrm{~d}$, e, it is clear that a thin coating of microscale clusters of rGO sheets successfully done over graphite electrode and the average thickness of the coating for ( $\mathrm{rGO} /$ $\mathrm{Gr})_{2}$ is $193.15 \mu \mathrm{m}$ over $\mathrm{Gr}$ (Fig. 10f). However, $\mathrm{rGO}$ enhances the overall surface area of the graphite electrode. Hence, the mass transfer rate improves; this can transform into better electrocatalytic performance. The FESEM of used $(\mathrm{rGO} / \mathrm{Gr})_{2}$ after 5 runs was carried out to check the coating's stability. From Fig. $10 \mathrm{~g}$, it shows $\mathrm{rGO}$ coating remain present over the Graphite surface, offers good stability of the coating. Actual images of $(\mathrm{rGO} / \mathrm{Gr})_{2}$ electrode, fresh and used shown in Fig. 10h.

\subsection{Contact angle}

The contact angle is an essential measure of the wettability of the surface of the graphite electrode. The higher is the contact angle, the lower becomes the tendency to wet the electrode surface with higher hydrophobicity [42]. From Fig. 11, it was observed that the contact angle for graphite electrode $(\mathrm{Gr})_{0}$ was $101.55^{\circ}$. The contact angle increased by the coating of $\mathrm{rGO}$ over the graphite electrode, having value $109.85^{\circ}$ and $112.3^{\circ}$ for $(\mathrm{rGO} / \mathrm{Gr})_{1}$ and $(\mathrm{rGO} / \mathrm{Gr})_{2}$, respectively, shows that the hydrophobicity of the electrode surface-enhanced considerably. As per the literature, the hydrophobicity enhancement indicated that the electrode's stability and catalytic activity improved [43].

\subsection{Stability of the coating}

The coating's long-term stability is also an important performance index for the electrochemical process to treat wastewater and future environmental applications [44]. Therefore, to check the coating's stability, the electro-oxidation process was repeated 5 times with the same ( $\mathrm{rGO} /$ $\mathrm{Gr})_{2}$ electrode, and the colour removal (\%) was observed. The colour removal (\%) was dropped from 96.69 to 91.72 after 5 runs. The decline in results can be described by releasing a small amount of $\mathrm{rGO}$ diffuse into the water (Fig. 12) [24]. The reason for the electrode's prolonged service life may be due to the improvement in hydrophobicity of the coated electrode [43]. The FESEM and XRD of used $(\mathrm{rGO} / \mathrm{Gr})_{2}$ electrode also represent the coating's 
Fig. 10 FESEM micrographs of graphite power (a), GO (b), the surface of $(\mathrm{Gr})_{0}(\mathbf{c})$, the surface of $(\mathrm{rGO} / \mathrm{Gr})_{1}(\mathbf{d})$, the surface of $(\mathrm{rGO} / \mathrm{Gr})_{2}(\mathbf{e})$, the cross-section of $(\mathrm{rGO} / \mathrm{Gr})_{2}(\mathbf{f})$, the surface of used $(\mathrm{rGO} / \mathrm{Gr})_{2}(\mathbf{g})$, actual images of $(\mathrm{rGO} / \mathrm{Gr})_{2}$ electrode, fresh and used (h)

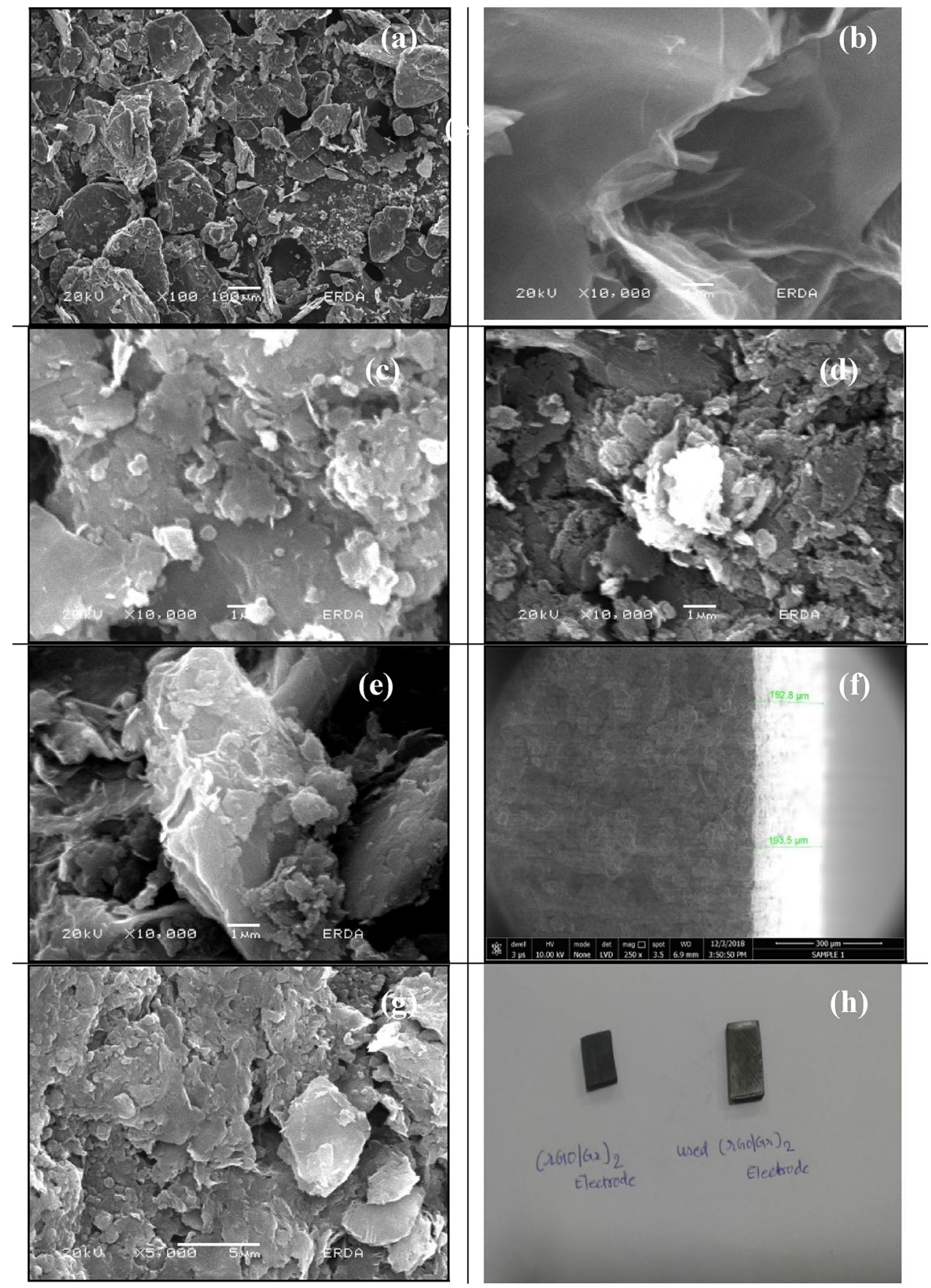

good stability. However, improvement in the stability of the coating could be the future scope of research.

\section{Conclusions}

The colour removal efficiency of the indirect electro-oxidation process for synthetic RTB21 dye wastewater was improved by modification of the surface of the graphite electrode using dip-coating of GO and reduced to $\mathrm{rGO}$ by a thermal method. GO was successfully synthesized using improved Hummer's method. The resultant graphite electrode, designated as $(\mathrm{Gr})_{0},(\mathrm{rGO} / \mathrm{Gr})_{1}$, and $(\mathrm{rGO} /$ $\mathrm{Gr})_{2}$, were examined by using FTIR, XRD, FESEM, and Contact Angle. FTIR and XRD analysis indicate that GO was successfully synthesized and coated over the pretreated graphite electrode. The results of the electrooxidation process were analysed with respect to the effect of operating process parameters such as current density $\left(\mathrm{A} / \mathrm{m}^{2}\right)$, initial $\mathrm{pH}, \mathrm{NaCl}$ as electrolyte concentration $(\mathrm{g} / \mathrm{L})$, and temperature $\left({ }^{\circ} \mathrm{C}\right)$. Per cent colour removal was improved by $10.5 \%$ and $25.80 \%$ using a modified 


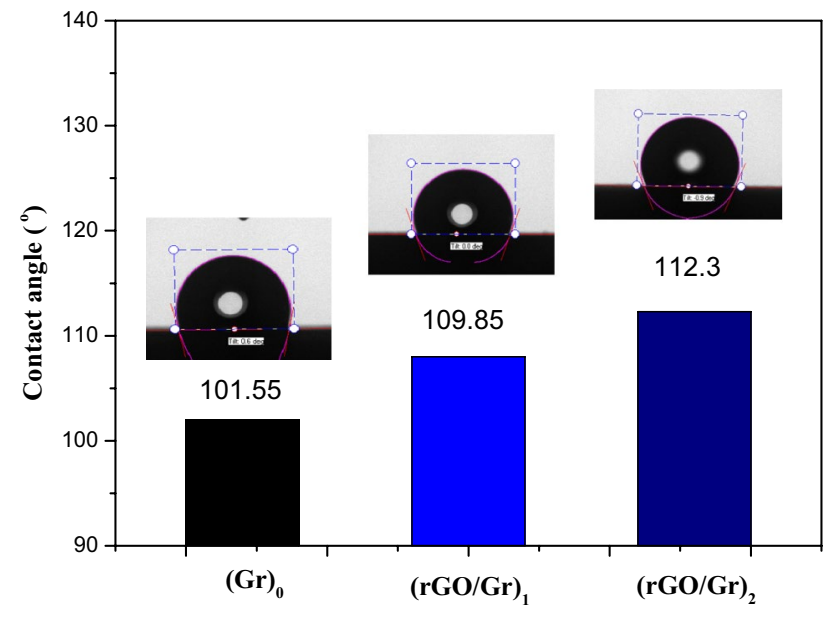

Fig. 11 Contact angle for $(\mathrm{Gr})_{0},(\mathrm{rGO} / \mathrm{Gr})_{1}$, and $(\mathrm{rGO} / \mathrm{Gr})_{2}$

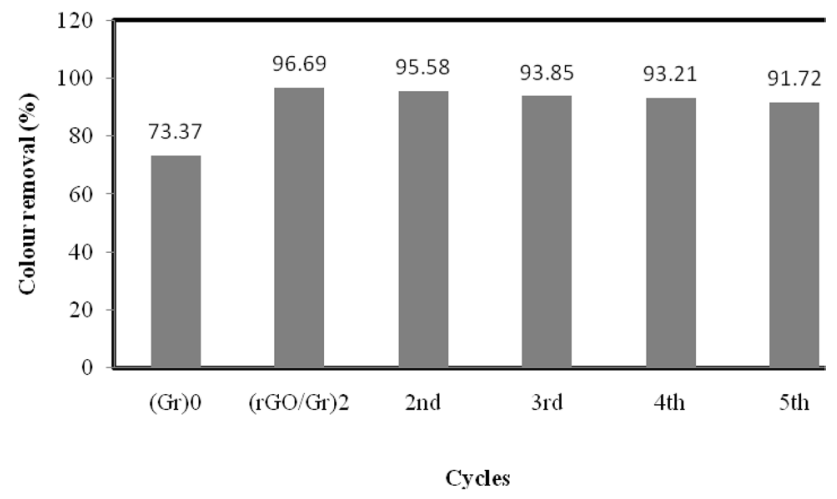

Fig. 12 Stability of the (rGO/Gr) $)_{2}$ over 5 cycles. Conditions: $7 \mathrm{pH}$, $200 \mathrm{~A} / \mathrm{m}^{2}$ current density, $2 \mathrm{~g} / \mathrm{L} \mathrm{NaCl}$ concentration, $30{ }^{\circ} \mathrm{C}$ temperature, and $15 \mathrm{~min}$ process time

graphite electrode $(\mathrm{rGO} / \mathrm{Gr})_{1}$ and $(\mathrm{rGO} / \mathrm{Gr})_{2}$, respectively, at $50 \mathrm{ppm}$ RTB21 dye concentration, 7.0 initial pH, $200 \mathrm{~A} /$ $\mathrm{m}^{2}, 2 \mathrm{~g} / \mathrm{L} \mathrm{NaCl}$ concentration, $30{ }^{\circ} \mathrm{C}$ temperature, and 15 min process time. The RTB21 decolourization by the indirect electro-oxidation process followed the pseudofirst-order kinetics, and the activation energy and Arrhenius constant $(A)$ value were estimated to be $23.42 \mathrm{~kJ} /$ mol, and 2022.32, respectively.

The data obtained in the present study could be used as guidelines for the design and scale up of the electrooxidation unit for possible commercial applications.

Acknowledgements The authors are grateful for the support to carry out analyses provided by the Shah-Schulman Centre for Surface Science and Nanotechnology (SSCSSN), Nadiad, Sophisticated Instrumentation Centre for Advance Research \& Testing (SICART), Vallabh Vidyanagar, and the Electrical Research and Development Association (ERDA), Vadodara.

\section{Compliance with ethical standards}

Conflict of interest Authors have no conflict of interest.

\section{References}

1. Li S, Wang L, Yang X, Wang Y (2017) Activated carbon produced from sugarcane bagasse waste as a low-cost dye-containing wastewater adsorbent for reactive turquoise blue removal. Desalination Water Treat 81:315-321. https://doi.org/10.5004/ dwt.2017.21105

2. Liu S, Li B, Qi P, Yu W, Zhao J, Liu Y (2019) Performance of freshly generated magnesium hydroxide (FGMH) for reactive dye removal. Colloids Interface Sci Commun 28:34-40. https://doi. org/10.1016/j.colcom.2018.11.004

3. Bilińska L, Blus K, Gmurek M, Ledakowicz S (2019) Coupling of electrocoagulation and ozone treatment for textile wastewater reuse. Chem Eng J 358:992-1001. https://doi.org/10.1016/j. cej.2018.10.093

4. Gangwar R, Rasool S, Mishra S (2016) Evaluation of cellobiose dehydrogenase and laccase containing culture fluids of Termitomyces sp. OE147 for degradation of Reactive blue 21. Biotechnol Rep 12:52-61. https://doi.org/10.1016/j.btre.2016.10.002

5. Can OT, Bayramoglu M, Kobya M (2003) Decolorization of reactive dye solutions by electrocoagulation using aluminum electrodes. Ind Eng Chem Res 42:3391-3396. https://doi. org/10.1021/ie020951g

6. Suen NT, Hung SF, Quan Q, Zhang N, Xu YJ, Chen HM (2017) Electrocatalysis for the oxygen evolution reaction: recent development and future perspectives. Chem Soc Rev 46:337-365

7. Daneshvar N, Behnajady MA, Mohammadi MKA, Dorraji MSS (2008) UV/H2O2 treatment of Rhodamine B in aqueous solution: influence of operational parameters and kinetic modeling. Desalination 230:16-26. https://doi.org/10.1016/j.desal .2007.11.012

8. Farhadi S, Aminzadeh B, Torabian A, Khatibikamal V, Fard MA (2012) Comparison of COD removal from pharmaceutical wastewater by electrocoagulation, photoelectrocoagulation, peroxielectrocoagulation and peroxi-photoelectrocoagulation processes. J Hazard Mater 219-220:35-42. https://doi.org/10.1016/j. jhazmat.2012.03.013

9. Khandegar V, Saroha AK (2013) Electrocoagulation for the treatment of textile industry effluent-a review. J Environ Manag 128:949-963

10. Sandhwar VK, Prasad B (2017) Comparative study of electrochemical oxidation and electrochemical Fenton processes for simultaneous degradation of phthalic and para-toluic acids from aqueous medium. J Mol Liq 243:519-532. https://doi. org/10.1016/j.molliq.2017.08.016

11. Panizza M, Cerisola G (2007) Electrocatalytic materials for the electrochemical oxidation of synthetic dyes. Appl Catal B Environ 75:95-101. https://doi.org/10.1016/j.apcatb.2007.04.001

12. Rivera M, Pazos M, Sanromán MÁ (2011) Development of an electrochemical cell for the removal of Reactive Black 5. Desalination 274:39-43. https://doi.org/10.1016/j.desal.2011.01.074

13. Kariyajjanavar P, Jogttappa N, Nayaka YA (2011) Studies on degradation of reactive textile dyes solution by electrochemical method. J Hazard Mater 190:952-961. https://doi.org/10.1016/j. jhazmat.2011.04.032

14. Qiao MX, Zhang Y, Zhai LF, Sun M (2018) Corrosion of graphite electrode in electrochemical advanced oxidation processes: Degradation protocol and environmental implication. Chem Eng J 344:410-418. https://doi.org/10.1016/j.cej.2018.03.105 
15. Bondarenko EA, Mazanik AV, Streltsov EA, Kulak Al, Korolik OV (2015) $\mathrm{SnO}_{2}$ /reduced graphene oxide composite films for electrochemical applications. Mater Sci Eng B 202:61-67. https://doi. org/10.1016/j.mseb.2015.10.002

16. Mousset E, Ko ZT, Syafiq M, Wang Z, Lefebvre O (2016) Electrocatalytic activity enhancement of a graphene ink-coated carbon cloth cathode for oxidative treatment. Electrochim Acta 222:1628-1641. https://doi.org/10.1016/j.electacta.2016.11.151

17. Li Y, Han J, Xie B, Li Y, Zhan S, Tian Y (2017) Synergistic degradation of antimicrobial agent ciprofloxacin in water by using $3 \mathrm{D} \mathrm{CeO} / \mathrm{RGO}$ composite as cathode in electro-Fenton system. J Electroanal Chem 784:6-12. https://doi.org/10.1016/j.jelec hem.2016.11.057

18. AkerdiEs'haghzadeBahramiArami AGZSHM (2017) Comparative study of GO and reduced GO coated graphite electrodes for decolorization of acidic and basic dyes from aqueous solutions through heterogeneous electro-Fenton process. J Environ Chem Eng 5:2313-2324. https://doi.org/10.1016/j.jece.2017.04.028

19. Li G, Xia Y, Tian Y, Wu Y, Liu J, He Q, Chen D (2019) Review_recent developments on graphene-based electrochemical sensors toward nitrite. J Electrochem Soc 166:B881-B895. https://doi. org/10.1149/2.0171912jes

20. Li Q, Xia Y, Wan X, Yang S, Cai Z, Ye Y, Li G (2020) Morphologydependent $\mathrm{MnO}_{2}$ /nitrogen-doped graphene nanocomposites for simultaneous detection of trace dopamine and uric acid. Mater Sci Eng C 109:110615. https://doi.org/10.1016/j. msec.2019.110615

21. Cai Z, Ye Y, Wan X, Liu J, Yang S, Xia Y (2019) Morphologydependent electrochemical sensing properties of iron oxidegraphene oxide nanohybrids for dopamine and uric acid. Nanomaterials 835:1-19

22. Li G, Wu J, Jin H, Xia Y, Liu J, He Q, Chen D (2020) Titania/electroreduced graphene oxide nanohybrid as an efficient electrochemical sensor for the determination of allura red. Nanomaterials 10:1-15. https://doi.org/10.3390/nano10020307

23. Wan X, Yang S, Cai Z, He Q, Ye Y, Xia Y, Li G, Liu J (2019) Facile synthesis of $\mathrm{MnO} 2$ nanoflowers/N-doped reduced graphene oxide composite and its application for simultaneous determination of dopamine and uric acid. Nanomaterials 9:1-16. https://doi. org/10.3390/nano9060847

24. Zhang Z, Meng H, Wang Y, Shi L, Wang X, Chai S (2018) Fabrication of graphene@graphite-based gas diffusion electrode for improving $\mathrm{H}_{2} \mathrm{O}_{2}$ generation in electro-Fenton process. Electrochim Acta 260:112-120. https://doi.org/10.1016/j.elect acta.2017.11.048

25. Aksu Z, Isoglu IA (2007) Use of dried sugar beet pulp for binary biosorption of Gemazol Turquoise Blue-G reactive dye and copper (II) ions: equilibrium modeling. Chem Eng J 127:177-188. https://doi.org/10.1016/j.cej.2006.09.014

26. Vaghela NR, Nath K (2019) Reclamation of model wastewater containing Rhodamine $B$ by electrochemical Fenton (ECF) process. J Sci Ind Res 78:624-628

27. Kang JH, Yoon Y, Song JH (2020) Effects of $\mathrm{pH}$ on the simultaneous removal of hydrogen sulfide and ammonia in a combined absorption and electro-oxidation system. J Hazard Mater 382:121011. https://doi.org/10.1016/j.jhazmat.2019.121011

28. Nandi BK, Patel S (2017) Effects of operational parameters on the removal of brilliant green dye from aqueous solutions by electrocoagulation. Arab J Chem 10:S2961-S2968. https://doi. org/10.1016/j.arabjc.2013.11.032

29. Rajkumar K, Mathkumar M (2017) Statistical optimization of electro oxidation process for removal of textile dye C.I. Reactive Blue 198. Int J Environ Sci Nat Resour 1:555570. https://doi. org/10.19080/ijesnr.2017.01.555570

30. Tahir H, Shah AR, lubal S, Kifayatullah H (2017) The statistical optimization of indirect electrochemical oxidation process for the treatment of dye from simulated textile discharge. Int J Environ Sci Nat Resour 2:555583. https://doi.org/10.19080/ ijesnr.2017.02.555583

31. Kariyajjanavar P, Narayana J, Nayaka YA (2013) Degradation of textile dye C.I. Vat Black 27 by electrochemical method by using carbon electrodes. J Environ Chem Eng 1:975-980. https://doi. org/10.1016/j.jece.2013.08.002

32. Rahmani AR, Godini K, Nematollahi D, Azarian G (2015) Electrochemical oxidation of activated sludge by using direct and indirect anodic oxidation. Desalination Water Treat 56:2234-2245. https://doi.org/10.1080/19443994.2014.958761

33. Sivodia C, Sinha A (2020) Assessment of graphite electrode on the removal of anticancer drug cytarabine via indirect electrochemical oxidation process: kinetics \& pathway study. Chemosphere 243:125456. https://doi.org/10.1016/j.chemospher e.2019.125456

34. Rajkumar K, Muthukumar M (2015) Response surface optimization of electro-oxidation process for the treatment of C.I. Reactive Yellow 186 dye: reaction pathways. Appl Water Sci 7:637-652. https://doi.org/10.1007/s13201-015-0276-0

35. Duan F, Li Y, Cao H, Wang Y, Crittenden JC, Zhang Y (2015) Activated carbon electrodes: electrochemical oxidation coupled with desalination for wastewater treatment. Chemosphere 125:205-211. https://doi.org/10.1016/j.chemospher e.2014.12.065

36. Rajkumar D, Palanivelu K (2004) Electrochemical treatment of industrial wastewater. J Hazard Mater 113:123-129. https://doi. org/10.1016/j.jhazmat.2004.05.039

37. Samet Y, Elaoud SC, Ammar S, Abdelhedi R (2006) Electrochemical degradation of 4-chloroguaiacol for wastewater treatment using PbO2 anodes. J Hazard Mater 138:614-619. https://doi. org/10.1016/j.jhazmat.2006.05.100

38. Körbahti BK, Artut K (2010) Electrochemical oil/water demulsification and purification of bilge water using $\mathrm{Pt} / \mathrm{Ir}$ electrodes. Desalination 258:219-228. https://doi.org/10.1016/j.desal .2010 .03 .008

39. Zhou M, Wu Z, Wang D (2002) Electrocatalytic degradation of phenol in acidic and saline wastewater. J Environ Sci Heal Part A Toxic/Hazardous Subst Environ Eng 37:1263-1275. https://doi. org/10.1081/ESE-120005985

40. Bera M, Chandravati GP, Maji PK (2017) Facile one-pot synthesis of graphene oxide by sonication assisted mechanochemical approach and its surface chemistry. J Nanosci Nanotechnol 18:902-912. https://doi.org/10.1166/jnn.2018.14306

41. Kartick B, Srivastava SK, Srivastava I (2013) Green synthesis of graphene. J Nanosci Nanotechnol 13:4320-4324. https://doi. org/10.1166/jnn.2013.7461

42. Elaissaoui I, Akrout H, Grassini S, Fulginiti D, Bousselmi L (2019) Effect of coating method on the structure and properties of a novel $\mathrm{PbO}_{2}$ anode for electrochemical oxidation of Amaranth dye. Chemosphere 217:26-34. https://doi.org/10.1016/j.chemo sphere.2018.10.161

43. Li X, Xu H, Yan W (2016) Fabrication and characterization of $\mathrm{PbO}_{2}$ electrode modified with polyvinylidene fluoride (PVDF). Appl Surf Sci 389:278-286. https://doi.org/10.1016/j.apsus c.2016.07.123

44. He H, Jiang B, Yuan J, Liu Y, Bi X, Xin S (2019) Cost-effective electrogeneration of $\mathrm{H}_{2} \mathrm{O}_{2}$ utilizing $\mathrm{HNO}_{3}$ modified graphite/polytetrafluoroethylene cathode with exterior hydrophobic film. J Colloid Interface Sci 533:471-480. https://doi.org/10.1016/j. jcis.2018.08.092

45. Güven G, Perendeci A, Tanyolaç A (2009) Electrochemical treatment of simulated beet sugar factory wastewater. Chem Eng J 151:149-159. https://doi.org/10.1016/j.cej.2009.02.008

46. Körbahti BK, Demirbüken P (2017) Electrochemical oxidation of resorcinol in aqueous medium using boron-doped diamond 
anode: reaction kinetics and process optimization with response surface methodology. Front Chem 5:75. https://doi.org/10.3389/ fchem.2017.00075

47. Bound U, Nanocomposite TO, Vianney YM, Rosalyn I, Angela S (2018) Solar based photocatalytic decolorization of four commercial reactive dyes. Indones J Chem 18:621-631. https://doi. org/10.22146/ijc.27549

48. Doan NM, Estrellan CR, Purnomo A, Gallardo S, Salim C, Hinode H (2012) Characterization and photocatalytic activity of nano- $\mathrm{TiO}_{2}$ doped with iron and niobium for turquoise blue dye removal. AJCHE 12:34-41

49. Matthews RD, Bottomley LA, Pavlostathis SG (2009) Palladiumcatalyzed hydrogen reduction and decolorization of reactive phthalocyanine dyes. Desalination 248:816-825. https://doi. org/10.1016/j.desal.2008.12.043

50. Yadav A, Mukherji S, Garg A (2013) Removal of chemical oxygen demand and color from simulated textile wastewater using a combination of chemical/physicochemical processes. I EC Res 52:10063-10071. https://doi.org/10.1021/ie400855b

Publisher's Note Springer Nature remains neutral with regard to jurisdictional claims in published maps and institutional affiliations. 